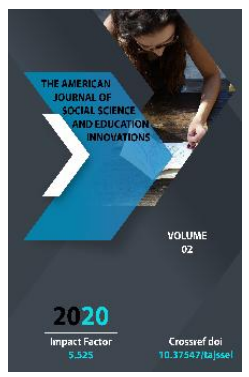

\title{
Decentralization In Uzbekistan Is An Important Pillar Of The Development Of Local Self-Government
}

\author{
Akhunov Muhammadamin Abduvasitovich \\ Andijan Machine Building Institute Department of "Humanities" Candidate of Economic \\ Sciences, Uzbekistan
}

Journal Website:

http://usajournalshub.c

om/index,php/tajssei

Copyright: Original

content from this work

may be used under the

terms of the creative

commons attributes

4.0 licence.

\section{ABSTRACT}

This article is devoted to the process of decentralization of the formation of civil society in Uzbekistan and the results of the gradual transfer of state functions, powers and responsibilities, first from the center to local authorities, and then from local self-government bodies to citizens' selfgovernment. As a unique system, the mahalla is analyzed as the basis for democratic reforms, citizens' approach to political and economic activity, and an approach to public affairs.

\section{KEYWORDS}

Decentralization, Uzbek model, central government, local government, public administration, civil society, democracy, action strategy, powers and responsibilities, neighborhood, citizens 'selfgovernment bodies, citizens' assembly.

\section{INTRODUCTION}

Decentralization is the process of transition or transition from a centralized system to a decentralized system. Decentralization is the transfer of responsibilities, duties, rights, powers and responsibilities from the central government to the territories, sectoral authorities and non-governmental organizations. In emergencies, at the risk of external and internal attacks, in economic crises, natural disasters, in the difficulties of transition periods, centralization, i.e. the chief reformer of the state, is acceptable. In developed countries, the process of decentralization begins to achieve further growth in periods of economic stability, growth and prosperity. Political and economic stability make this possible. For Uzbekistan, which is transitioning from a totalitarian system to a civil society, decentralization is becoming a vital necessity. Uzbek scientists $A$. 
Oripov, B. Juraev, O. Husanov, M. Kyrgyzbaev, R. Jumaev, Sh. Jalilov, F. Musaev, M. Qorieva have published scientific works and articles on these issues. The specifics of decentralization in Uzbekistan will be further discussed in the article.

\section{THE MAIN PART}

\section{PECULIARITIES OF DECENTRALIZATION IN UZBEKISTAN}

Today, Uzbekistan is becoming a rapidly developing country recognized by the world community. After gaining independence in 1991, the formation of a democratic state and civil society based on the rule of law based on a market economy has become a strategic task and is progressing rapidly along this path. Having carried out wide-ranging reforms in the political, economic, social, legal, spiritual and cultural spheres from 1991 to 2016, our people, which has gone through hardships from totalitarianism to democratic development, is entering a new stage of development. These processes required a high level of activity, patriotism, confidence in the future, great energy and enthusiasm from our people. According to Vasilev, the processes of decentralization in democratic and totalitarian states are different. [1] In the process of transition of the economy to free market relations, a number of responsibilities, powers and functions of the central government began to be gradually transferred to local authorities, citizens' self-government bodies, mahallas. It was a practice based on local traditions of decentralization in the era of the idea of "from a strong state - to a strong civil society." Article 56 of the Constitution of the Republic of Uzbekistan states that "trade unions, political parties, societies of scientists, women's, veterans' and youth organizations, creative associations, mass movements and other associations of citizens registered in the Republic of Uzbekistan are recognized as public associations" 2]. This was to create legal opportunities for civil society institutions, non-governmental non-profit organizations to operate in accordance with the law. In the early stages of independence, Uzbekistan abandoned such a model as "shock therapy" and created the Uzbek model, which has become a strategy for the development of our world-famous future. The Uzbek model is based on the following five principles: 1. The supremacy of the economy over politics - economic reforms should never lag behind politics, it can not be subordinated to any ideology. Both internal and external economic relations must be free of ideology. 2. The state is the main reformer. The state must set priorities for reform during the transition period, develop and implement a policy of change, and overcome the opposition of ignorant and conservative people. 3. Laws and the priority of their observance. This means that the new Constitution and laws adopted in a democratic way must be respected by all without exception and strictly adhered to. 4. Carry out a strong social policy, taking into account the demographic composition of the population. Simultaneously with the introduction of market relations, effective measures must be taken in advance to ensure social protection. 5. Slow, gradual transition to a market economy - the transition to a market economy should be carried out step by step, taking into account the requirements of objective economic laws, without the "revolutionary leaps" of the past, that is, in an evolutionary way [3].

The idea of the state - the main reformer does not deny decentralization, but rather gives this process an evolutionary, step-bystep character. Democratic reforms make decentralization a necessity of life. $T$. 
According to Falletti, decentralization is a set of processes carried out primarily by the state itself, aimed at reforming the system of government and the transfer of powers, resources and responsibilities of the central government to local authorities. [4] In Uzbekistan, the state was working to gradually transfer its functions, first from the center to local authorities, and then from local government to citizens' self-government bodies and non-governmental non-profit organizations. Decentralization means the return of centralized powers and responsibilities to subordinate bodies provinces, cities, districts, and finally to mahallas, which are citizens' self-government bodies, and through them to citizens, that is, to the place where they received them. Decentralization is the beginning of local and regional democracy. Neighborhoods and regions, of course, with the consent of the population, with the opportunities and potential, carry out the tasks, obligations, responsibilities, problems that can not be performed from below.

Decentralization is an extremely difficult process between central and local government bodies, with the transfer of functions, powers and responsibilities. This process involves interrelationships such as finance, administration, control, regulation, accountability and accountability. The main purpose of decentralization is to increase the efficiency of the public sector and improve the living standards of the population.

According to the Constitution of the Republic of Uzbekistan, the system of public authorities is defined at three levels: central - republican level organizations, middle - regional level organizations and lower - district and city level organizations. Neighborhoods, which are citizens' self-governing bodies, today occupy the fourth level as an independent link.
In Uzbekistan today, it is important to carry out the process of decentralization in two directions: economic decentralization and political-administrative decentralization. Economic decentralization is achieved through liberalization, liberalization of key sectors of the economy and compliance with the laws of a market economy. This process is being implemented taking into account the experience of developed countries, abandoning the planned economy:

$\checkmark$ denationalization of enterprises and the creation of new management structures;

$\checkmark$ establishment of joint-stock companies and joint ventures;

$\checkmark$ abandonment of directive (mandatory) planning of enterprises;

$\checkmark$ price liberalization;

$\checkmark$ creation of a system of market relations;

$\checkmark$ privatization - strengthening privatization and the formation of a class of real owners;

$\checkmark$ formation of market infrastructure and financial market;

$\checkmark$ Entrepreneurship, small and medium business development;

$\checkmark$ attraction of foreign economic relations and international investments;

$\checkmark$ reduction of the ministries, institutions and courts of the republic, other administrative structures and transfer of their powers and responsibilities to the following local organizations and enterprises;

$\checkmark$ Reduction of state control functions [5].

$\checkmark$ Since independence, the tasks listed above have largely been set in motion and positive results have been achieved.

In the political-administrative decentralization in Uzbekistan, the concept of local government should be distinguished in two ways:

- First, they are local government bodies, subordinate to the central authorities at 
the regional, district and city levels and accountable to the population of their territories. They are not elected by the people, but rather appointed by higher organizations;

- secondly, mahallas, citizens 'selfgovernment bodies, citizens' assemblies. The governing body of the mahalla is elected by the people for a certain period of time and is accountable to the voters. Local self-government serves as a "school of democracy."

Decentralization is the basis of local selfgovernment.

The first historically formed unit of the population in Uzbekistan is the family, and the next unit is the mahalla. Similar to the Uzbek mahalla, the appropriate social unit and structure is almost non-existent in other countries. The neighborhood is a bridge that connects people after family to society. In Uzbekistan, a mahalla is an administrativeterritorial unit, an association, which has been formed and operated for centuries under certain historical conditions. A neighborhood is a unique social organization, a community, organized for self-government in order to live together in peace and harmony, a unifying space in a small area consisting of certain streets of citizens. The mahalla is an ancient organization in Uzbekistan with a history of several thousand years, a value inherited from our ancestors. In the Vedevdot section of the 2,700-year-old Avesto book, he tells us about the neighborhood with the phrase, "Ahuramazda is a community of honest, hardworking people." Well-known historian Abu Ja'far Narshahi in his book "History of Bukhara", written in the IX century, reports that 1100 years ago in Bukhara there were 19 large self-governing mahallas. According to historical sources, the number of mahallas in Tashkent reached 150 in the 18th century and 200 in the 19th century. Today, about a thousand mahallas in the capital are united by citizens' self-government bodies. Today, the number of citizens' assemblies and selfgoverning bodies - mahallas in Uzbekistan is more than 10,000.

Thanks to independence, the mahalla began to restore its historical status, ancient, traditional and legal status. Citizens' selfgovernment in Uzbekistan means the independent activity of citizens guaranteed by the Constitution and laws of the Republic of Uzbekistan in resolving issues of local importance based on their interests, national and spiritual values, historical traditions and customs.

In Uzbekistan, the mahalla institute is the main link of citizens' self-government. In honor of independence, when the state set itself the task of building a just civil society, the mahalla was identified as the basis of a new society of the future, and the concept of "Mahallas of the XXI century" was developed. Adoption of the Decree of the President of the Republic of Uzbekistan dated September 12, 1992 "On the establishment of the Republican Charitable Fund" Mahalla "PF-472 led to positive results.

As stated in Article 105 of the Constitution of the Republic of Uzbekistan, "assemblies of citizens in mahallas are self-governing bodies, which elect a chairman (aksakal). The procedure for electing local self-government bodies, the organization of their activities and the scope of their powers shall be determined by law"[6].

Although local public authorities and citizens' self-government bodies are separate independent structures, their interaction is of great importance in achieving social development. In addition to their specific functions, they also have the following general functions: 
- provides practical assistance to citizens in exercising their right to participate in the management of public and state affairs;

- Assists in the implementation of social and economic activities in the community. [7]

- In the first years of independence, the following main tasks were set for the restoration and development of a unique system as a mahalla:

- further strengthening of state support to the mahalla;

- Comprehensive strengthening and development of the legal framework of the mahalla;

- further strengthening the mahalla as an integral part of the political, economic and spiritual life of our society, a system of subordinate management;

- organization of all material and financial conditions of the mahalla;

- to establish a legal basis for the mahalla's relations with district and city khokims, social, non-governmental and political organizations.

The implementation of these tasks has further enhanced the prestige of the mahalla in the community. The rule of law, based on a socially oriented market economy, has played a special role in building a democratic state and civil society.

We know that in today's civil society, public organizations that connect citizens with government agencies and act in their interests have important powers. In developed Western countries, political parties and other public associations are the main ones, and non-members or there will be no direct organic connection between citizens who do not participate in its work and government agencies. In the context of Uzbekistan, the mainstay of civil society is the mahalla citizens' self-government bodies. Here, citizens live in the neighborhood regardless of who or what type of activity they are engaged in. This means that as long as every citizen lives in the neighborhood, this neighborhood acts as a bridge connecting the citizen with the state body, ensuring their interests. Public opinion, which has a strong influence in the neighborhood, regulates the behavior and relationships of citizens living in the neighborhood on the basis of justice and moral criteria. That is why citizens' selfgovernment bodies are literally becoming the mainstay of civil society. Public opinion on political, economic and social issues in our society is analyzed and formed in the neighborhoods. Therefore, it can be observed that the active participation of the mahalla institution in the implementation of public control, which is an integral feature of civil society, is growing.

In Uzbekistan, towns, villages as well as mahallas in cities, towns, villages are citizens' self-government bodies. Citizens' selfgovernment bodies are not part of the system of public authorities and exercise their powers granted by law within the relevant territory. Citizens' self-government bodies exercise the rights of a legal entity, have a seal of the established form and operate on the basis of the Charter approved by them.

The financial basis of the activities of citizens' self-government bodies in Uzbekistan consists of its own funds, local budgets, sponsorships of legal entities and individuals, as well as other funds provided by law, and independently manages funds in bank accounts in the manner prescribed by law. The Council of the Citizens 'Assembly shall report to the Citizens' Assembly on a quarterly basis on the use of financial resources. Based on the results achieved since 2016, a new path of development of Uzbekistan has been set and an action strategy for the further development of our country has been developed. 
Decree of the President of the Republic of Uzbekistan dated February 7, 2017 No PF-4947 "On the Strategy for further development of the Republic of Uzbekistan" was adopted to identify priorities for the development of all spheres of state and public life in our country and their gradual implementation.

In order to gradually implement the Action Strategy, the decree sets out the procedure for its implementation and implementation in our country, based on the names given to the years, with the adoption of state programs for each year.

The Decree approved an important document in our country - the Action Strategy for the five priority areas of development of the Republic of Uzbekistan for 2017-2021 and the State Program for the implementation of the Action Strategy.

The State Program consists of Section V, Part I, which focuses on improving the system of state and society building, including improving public administration, including strengthening the role of the Oliy Majlis and political parties in public administration, radically improving the quality of lawmaking, improving public control, as well as measures to strengthen the role of the community in public life.

Section II is entitled Ensuring the Rule of Law and Further Reforming the Judicial System. Section III outlines measures for further development and liberalization of the economy.

Section IV "Development of the social sphere" is aimed at increasing employment, implementation of targeted programs for affordable housing, development and modernization of road transport, engineering and communication and social infrastructure, health care reform, to take measures to improve the quality of education.

Section V, entitled "Ensuring Security, Interethnic Harmony and Religious Tolerance, and pursuing a well-thought-out, mutually beneficial and practical foreign policy." [8] Today, the Uzbek people are strengthening the foundations of civil society by implementing democratic reforms.

\section{CONCLUSION}

The analysis shows that decentralization is gradually taking place in Uzbekistan. The transfer of powers and responsibilities from central authorities to local authorities and from them to citizens' self-government bodies is a process carried out through political, administrative, economic, social, legal, spiritual and psychological training. In our country, which is building a democratic state based on the rule of law and a civil society based on a market economy, positive results are being achieved in this area.

\section{REFERENCES}

1. Vasiliev V.I. Local government. Educational and scientific-practical manual. Moscow, 1999, 9-bet.

2. The Constitution of the Republic of Uzbekistan. T., 2019.

3. Gafarli M., Kasaev A. The Uzbek model of development: peace and stability are the basis of development. Tashkent: Uzbekistan, 2001. -430 p.

4. Falleti T. (2004). A Consistent Theory of Decentralization and Its Impact on the Balance of Power in Relations Between Public Authorities: A Case Study of Latin America in a Comparative Perspective. 3-27-b.2007 yil 7 January. http://www.nd.edu/ kellogg / publications / workin-gpapers /WPS/314.

5. Saidova G. Decentralization as a prerequisite for local self-government. 
Doi: https://doi.org/10.37547/tajssei/Volume02Issue09-01

On the way to the UN Charter: on local self-government of citizens: demands of the century. T., 2001., 11-12 betlar.

6. The Constitution of the Republic of Uzbekistan. T., 2019. Article 105.

7. Glebova A.N. The main trends in the democratic modernization of local self-government. Service in Russia and abroad. 2017.13

8. Decree of the President of the Republic of Uzbekistan dated February 7, 2017 No PF-4947 "On the Action Strategy for further development of the Republic of Uzbekistan." Collection of Legislation of the Republic of Uzbekistan, 2017, No. 6 , Article 70 